\title{
Deconstructing the Discursive Construction of Environmental Colonialism in Native America: A Study of Leslie Marmon Silko's Ceremony and Almanac of the Dead
}

\author{
Quratulain Mughal ${ }^{1} \&$ Wajid Hussain ${ }^{2}$ \\ ${ }^{1}$ National University of Modern Languages (NUML), Islamabad, Pakistan \\ ${ }^{2}$ Faculty Social Sciences, Shaheed Zulfikar Ali Bhutto Institute of Science \& Technology (SZABIST), \\ Islamabad, Pakistan \\ Correspondence: Quratulain Mughal, National University of Modern Languages (NUML), Islamabad, Pakistan. \\ E-mail: mughal.quratulain@yahoo.com
}

\author{
Received: March 17, 2019 Accepted: May 2, 2019 Online Published: May 29, 2019 \\ doi:10.5539/ijel.v9n3p365 URL: https://doi.org/10.5539/ijel.v9n3p365
}

\begin{abstract}
This paper deconstructs the Europeans' environmental colonialism in Native America and, in that, elucidates that the rhetorical tactics and fundamental motivations, which are employed to 'other' people, are essentially the same as those used to 'other' environment and nature with all of its ecological subjects. A qualitative content analysis, the study investigates this notion in Leslie Marmon Silko's Ceremony and Almanac of the Dead in the light of the joint critique of biocolonization and critical discourse analysis. Linguistically, it applies Fairclough's approach of critical discourse analysis focusing on three scenarios of discourse: an acceptance of difference, an accentuation of difference, and an attempt to resolve difference. Through this critique of power, hegemony and identity, the research highlights the Natives' objectification and representation by the white colonizer and the subsequent resistance by the Natives. The analysis reveals how the process of environmental colonialism, specifically biopiracy and biocolonization, is naturalized by the colonizer through discourse structure. Additionally, it deconstructs this discourse structure to attempt to resolve the difference exploited by the colonizer to exercise their colonial practice over the natives and their environment. Hence, the study discursively adds to the existing solutions to combat the environmental colonialism.
\end{abstract}

Keywords: colonialism, environment, biocolonization, critical discourse analysis

\section{Introduction}

The power structure has significantly exploited the notion of man's superiority over nature and environment. Moreover, this exploitation is accomplished by discourse structure, as Luckett $(2004$, p. 512) suggests that the concept of environment is subject to human thinking "which is outside the system". The relevant hegemonic practices have sustained themselves on discourse with associated rhetoric that creates, in Foucault's words, 'a regime of truth' and establishes power structure to be maneuvered by the socially dominant. The hegemonization of the powerful requires from them the establishment and dissemination of ideological common sense, a process which Fairclough (1992, p. 12) terms as "Naturalization".

Moreover, it is this process of "Naturalization" that has also legitimized for the colonizer their colonial right to rule over the colonized and their environment. One associated concept with all its practical application is bioclolonization, which encompasses different policies and practices that the dominant colonial culture can draw on to retain and expand its control over the natives and their lands. Biocolonization is "a new form of ecological imperialism" which encompasses the wide-ranging "biopolitical implications" of western trends and experiments of technology (Huggan \& Tiffin, 2006, p. 14). It has, especially, facilitated the colonizer in the commodification of indigenous resources and knowledge.

Additionally, biocolonization involves exploitation of the natural resources and the land of the natives through the misuse of power, so it re-echoes the concepts of ideology and power. In biocolonization, therefore, the eco-poco discourse is deconstructed (it is detached from its prior impartial meanings) and reconstructed (by global colonial power structures to accomplish explicit purposes) with the construction of new ideologies and power relations. Tong $(1998$, p. 48) views that these power structures and ideologies are imposed by "socially 
constructed" colonial discourse.

The study seeks to view this concept in eco-poco discourse and aims to ascertain how a power discourse suits the environmental agenda of the colonizer. It exposes this agenda through the lens of critical discourse analysis focusing on Norman Fairclough's critique of acceptance of difference, and an accentuation of difference. Moreover, it also attempts to resolve the issue of this 'othering' exploited in the environmental colonialism.

\subsection{Locating the Inquiry}

The mutual interaction of the natives' environmental rights and postcolonial discourse is the significant aspect of Native American writers. Leslie Marmon Silko's writings deal with the issues of biocolonization. Being a native herself, she produces a distinct discourse in which the natives struggle against colonial power structures to 'demystify' and 'unnaturalize' their construed identity. Colonial rejection of the 'other objects' (natives and nature) makes her novels suitable for the study of discourse in the perspective of Biocolonization. She highlights how the relationship of American Indians with environment has been used as the mirror imagination of hegemonic Euro-American ecologies. This paper investigates her Ceremony and Almanac of the Dead of in the light of biocolonization and critical discourse analysis.

\subsection{Research Objectives}

This paper aims at meeting the following research objectives by analyzing Silko's Ceremony and Almanac of the Dead of in the light of the perspectives of biocolonization and critical discourse analysis: to examine the extent to which the discourse of the colonizer serves their environmental agenda; and to ascertain the way this environmental agenda of the colonizer is deconstructed by a counter narrative as established by Silko as a native American writer.

\subsection{Research Questions}

1.3.1 To what extent does the environmental discourse serve the environmental agenda of the colonizer in Silko's Ceremony and Almanac of the Dead?

1.3.2 How does Silko deconstruct, through her counter narrative, this environmental agenda of the colonizer?

\subsection{Biocolonization as Environmental Colonialism}

Graham Huggan and Helen Tiffin view biocolonization as "a new form of ecological imperialism" which encompasses the wide-ranging "biopolitical implications" of western trends and experiments of technology and specify it with the example of invasion of indigenous knowledge and property and 'biotechnological supermatism'. The critics explain that scientific knowledge is meant to fulfill self-serving needs of the West and sustain the political power it carries with itself (Huggan \& Tiffin, 2006, p. 14).

Additionally, Lemke (2011, p. 56) links Biocolonialism with biopolitics, which "denotes a politics that deals with life', whereas Ann Laura Stoler (1995) reconstituted this concept in terms of postcolonialism. The lectures of the latter on Society Must Be Defended focus on the earliest rendezvous of biopolitics and postcolonialism. She has analysed the production of bourgeois order of the Europeans in the 19th century Dutch East Indies, and in her analysis she has ascertained the connections between sexuality and race in colonial power functioning. She has also illustrated how the ideologies, practices and policies of the imperial science generate biocolonialism.

\subsection{Biocolonization and the Poststructuralist Perspective}

Whereas biocolonization involves exploitation of the natural resources and the land of the natives through the misuse of power, it re-echoes the concepts of ideology and power. Biopolitical critique also challenges the imperial ideology which provides the rhetoric for justification of the policies and practices of western knowledge. This is how the theoretical stance of the critique of biocolonization comes to be aligned with the poststructuralist and postmodernist perspective as Michel Foucault calls it 'Biopower', which refers "to the totality of techniques for the social control of the humans" (Nadesan, 2008, p. 93). Foucault's critique focuses on the relationship between 'power and knowledge' (Foucault, 1972, p. 71). His discussion meditates between subjects and objects. His work echoes the liaison between social practices and discourse and social practices. He thinks that discourses can be "treated as practices which systematically form the objects of which they speak" (Foucault, 1972, p. 74).

Critical Discourse Analysis points out the same hidden meanings of multiple discourses and aims at exposing them (Fairclough, 1992, p. 9). Its critical approaches not only demonstrate how identities and social relations are constructed by these practices but also comment on the intervention of societal power with discursive practices (Fairclough, 1992, p. 12). Deducing from this point, discourse is conceptualized with ideological and political power which serves to naturalize and contest particular power relations. 
So, the ideas of biocolonization serve as a 'critical approach' that not only echoes the concept of societal power intrusion through these constructed identities but also invites resistance. The identical phenomenon of 'objectification' has been discussed by Ruth Wodak. She claims that with the transformation of discourse "the object not only changes its meanings, but it becomes a different object; it loses its previous identity" (Wodak, 2001, p. 42). These objects with new meanings produce completely new discourse based on 'False distinction' of dualism (particularly 'us' and 'them' debate). This dualism makes the root cause of first dominating the 'others' and then exploitation their identities along with their environment.

The study requires, therefore, a synthetic approach for a linguistic analysis of the selected texts in the light of the biocolonization perspective and, thus, applies Fairclough's discourse scenarios (Fairclough, 2003, pp. 41-42) to establish the required framework. These scenarios can be viewed along with the ideas of biocolonization in three ways. The first scenario is an acceptance of difference, which is based on Fairclough's concept of 'Naturalization'. It rests on his idea of intertextuality that he derives from Bakhtin (1981) in which he argues that "any utterance is a link in a very complexly organized chain of other utterances with which it enters into one kind of relation to another" (2003, p. 42). According to him every text 'appears in itself as dialogical in one way or another' (p. 42). The dialogic self is not an entity at its own but it emerges from social processes in history. These processes act as stimuli to create differences among individuals and societies. The 'dialogic self' describes the conceptualization of the superiority of the colonizers by creating the difference of power positions. Moreover, this self can be described as a microcosm of colonization - the outsider/the insider, the native/the nonnative, the nature/the culture. This microcosm has to relate itself to the wider world (colonial territories) in which it must function (to create difference, show superiority and, in turn, rule). So, the dialogical self of the colonizers localized itself in space and time of the natives to become a part of a broader whole (as civilized and superior). Similarly, biocolonization describes the formation of identities along with its effect on society and history. Val Plumwood (2001, p. 5), links dualistic thinking of 'reason cantered culture' that has not only served to sustain colonial dominance but also ruined the "biophysical limits of the planet". The said critic reinforces that to perfectly view the patterns and practices of biocolonization, first the philosophical basis of the representation and identification of the native identities need to be reconsidered. Hence biocolonization relates the practice and theory of race and environment in a way that "the oppression of one is directly connected to or supported by the oppression of the 'other"' (Curtin, 1990, p. 145)

The second scenario is an accentuation of difference, which refers to the conflict that rises due to the creation of difference. With the passage of time certain discourses become predominant and start delivering the intended motives. In critical terms, discourse takes the form of hegemony (authority of a state over others). Fairclough (1989, p. 1) explains how the 'differences' take forms of 'assumptions' and then serve as hegemony (the power to rule). According to him, discourses implemented through texts or talks constitute power that in turn produces policies and practices that suit their producers. These discourses inculcate new identities and new ways of being. For example, new social and economic formation now commonly depends on 'newly formed subjects'. Similarly, the native subjects (which are newly formed due to the acceptance of difference) are used for the economic purposes (materialization of difference) of the colonizers. In Plumwood's words these subjects (nature, native and animals) become 'dispensable' when their existence does not fulfill the imperial needs. As soon as they come in "a permanent service to them", they become "replenishable resource" (Plumwood, 2001, pp. 4-5). For Huggan and Tiffin (2010), this objectification also leads to the construction of dominant other against nature. This construction not only hierarchizes life forms but also results into the colonial exploitation of natural resources (p. 7).

The third scenario is an attempt to resolve difference. This scenario symbolizes a dialogical function. It discusses how, with the passage of time, one discourse gets replaced by another. It creates a new discourse which regulates our way of thinking. We see new struggles emerging that resist hegemony, as Fairclough argues that although ideological and political powers always intertwine the discourse yet discourse also serves to naturalize and contest particular power relations. Moreover, the purpose of critical discourse analysis is not only to reveal underlying meanings but also to create new ways to reduce disadvantages of the power system (Fairclough, 1992, p. 9). Hence it serves as an attempt to equal social relations. Likewise, biocolonial literature not only serves as a mirror to highlight colonial exploitation of native environment but also attempts to provide means to solve this issue. Moreover, at the present time, due to the extent and the intensity of environmental problems plaguing our planet, biocolonial literature strives to sensitize the readers on environmental issues and help them to adopt an environmentally responsible behavior.

This study synthesises the perspective of biocolonization and critical discourse analysis to understand materialistic underpinnings of postcolonial environmental discourse. Secondly, this cross fertilization of critical 
discourse analysis and biocolonization resolves that the colonial formation of new ideological identities and practices of power can be retrieved for the production of better anticolonial discourse.

\section{Methodology}

This study involves qualitative content analysis as its research method. Theoretically, it applies the concept of biocolonization and critical discourse analysis for the textual analysis of Silko's Ceremony and Almanac of the Dead. Moreover, it rationalizes the alignment of these concepts under theoretical triangulation which encourages a qualitative research to investigate a question from multiple views to strengthen research findings (Patton, 2002, p. 453). Contextually, the combination of these concepts suits this study because the critique of biocolonization raises concerns about the colonizer's legitimization of the environmental exploitation of the colonized, whereas critical discourse analysis exposes the relevant discourse practices that suit the agenda of the powerful and also helps in deconstructing these practices. The study specifically focuses on Fairclough's three-dimensional model (Fairclough, 2003, pp. 26-27) and, in that, it focuses on the following three scenarios of discourse analysis (Fairclough, 2003, pp. 41-42): an acceptance of difference; an accentuation of difference; and an attempt to resolve difference.

\section{Discussion}

\subsection{An Acceptance to Difference}

The colonizer has always required social and cultural superiority in order to maintain their empire. Their attempt results in the acceptance of cultural and social subordination of the 'other'. This acceptance has facilitated them to exploit natives' lands, labor, and natural resources. Moreover, it is this acceptance of difference which has "legitimized" the colonizer's domination of the natives. Consequently, the natives have always been pushed to the social periphery of the geopolitical enterprise. The 'other' has come to exist through the exploitation of the dichotomy resulting from the weakness of the natives against the colonial power. This 'otherness' provided the colonizers with the 'moral responsibility' to feel 'the white man's burden' and execute their policies accordingly.

Silko's novels recreate the praxis of this colonialism. In ceremony, she highlights through the character of Tayo how natives constitute the other. Tayo owns a land that shows his 'second-class citizenship' as a Native American. Moreover, his mixed blood disrupts his domesticity and dissociates him from his bloods. His aunt, especially, opposes him most. Being mixed-blood he, therefore, finds himself in a vacuum of identity, tilting to neither side (Native or Euro-American). Natives like him are managed by the Euro-Americans both, physically and emotionally, in such a way that defines and objectifies the 'otherness' of the former. However, this management is conditional and may need reconsideration as well. For example, when the services of the Natives like Tayo are required for a war in defense of the USA, they are treated as equal citizens or, at least, no consideration is paid to their inferior status. But, once the war is over, they are demoted to the level of 'other' again and, hence, they return to depravity, drunkenness and violence again.

The stereotype of othering is also exemplified by another character named Emo. He is so excited for his selection in war that he takes pride and delight in his exhibition as other. His interests get aligned with national interests and he feels jubilant that "'anyone' can fight for America.... in a time of need" (Silko, 1986, p. 64). The word 'anyone' has twofold implication contextually: 'anyone' denotes socially inferior 'other' and advocates the fact that these 'others' are subjected to the demands of the colonial powers. He starts thinking about himself as 'superior' and 'civilized'. He also signifies the power he holds as 'the national soldier'. Ironically, Tayo does not belong to the nation of the colonizers. Moreover, his thinking of himself as civilized and superior further reconfirms the colonial power discourse. He also carries with him the teeth which he has robbed from a dead Japanese soldier. He used to mark his 'power' with his 'authority' and capability to kill other human beings. He "fed off each man he killed, and the higher the rank of the dead man, the higher it made Emo" (p. 61). The fact that his self-made superiority is marked by the killing of other humans is paralleled with the colonizers' brutal treatment of others. Besides being 'made up' represents that Tayo does not own his true identity. This identity, which has been constituted by the destruction of the other human, has empowered him to feel as 'powerful' as the Euro-Americans are against people like him. He has always been objectified and then discarded by 'his country's establishment' (p. 62).

An additional example of 'social dominant other' can be seen in the rigid and oppressive social order that Auntie favors. She echoes her 'strong Christian values', which establish her religious superiority as the dominant other. Even her own self being identified as 'cross' labels her as a clean chart which can only be identified via 'strong religious values'. She has a belief that for the safety of her family reputation, she needs the cross to be worn all the time. She wants her Laguna family to be the 'model' that outpaces all others in the reservation. Her desire of being labeled as a 'model' mimics the role play of the colonizers. She, like her superior other, wants to influence 
all the people around her. She does not like Tayo to be in her house because his mixed blood opposes the idea of the righteousness she struggles to sustain. Tayo's mental instability not only offers her a chance to exhibit her flexibility but also gives her a chance to stay in power: "She needed a new struggle, another opportunity to show those who might gossip that she had still another unfortunate burden which proved that, above all else, she was a Christian woman" (Silko, 1992, p. 30). Her 'struggle' to release her 'burden' as a Christian corresponds with the colonial mission of civilizing the 'uncivilized'. She also wants his son Rocky to 'throw away' the native ways and 'adopt' Euro-American ways. By doing this, like her superior other, she wants to assimilate the 'inferior' identity of her son.

Silko also highlights the colonizer's utilization of the social resources of discourse to naturalize their environmental agenda. She highlights how prestigious European schools contravene Native values by teaching science through "tubful of dead frogs, bloated with formaldehyde" (Silko, 1986, p. 194). The novel Ceremony, for example, shows a girl trying to communicate to her teacher that killing animals like frogs for scientific experiments may invite the wrath of nature in form of terrible floods. The girl's request provokes the teacher's laughter. Similarly, Tayo's teacher also asks him to kill flies because "they are bad and carry sickness" (p. 101). Obeying his teacher, Tayo feels it "fun to chase them" (p. 101). He 'proudly' kills many flies, collects their piles and shows them to his uncle. Tayo's act disappoints his uncle immensely who shares with him how once people suffered from an enormous drought due to a similar violation of nature until a fly entreated on their behalf and saved them "Since that time the people have been grateful for what the fly did for us" (p. 101). The uncle struggles to resist the emerging discourse of the colonizer.

\subsection{Accentuation of Difference}

In the context of the study, this stage starts with the colonial power commodifying and marketing the indigenous communities and their land and culture. More importantly, the colonizer has made the indigenous bodies and minds to serve as a 'territory' to be invaded, explored and controlled for the vested interests of the former. The natives are exhibited as 'exotic and wild entities' and, so, something to be visited and explored. Silko deconstructs the colonizer's attempt to naturalize the difference which they do through myths and rituals in the indigenous land. For this she cites the example of Gallup Ceremonial. It is the public ceremony which is held in the native Indian town of Gallup situated on the borders of the reservation. The event, which is organized by 'three white men' and the town's mayor, is held annually to open business avenues for both non-natives and natives. Dancers are invited from different native tribes, who are paid for their 'performance'. Ironically no native is involved in the organization of traditional event. Moreover, the tradition is seen as a 'performance' to be enjoyed. The event is solely intended for the entertainment of whites. Interestingly, the town remains neglected for the rest of the year.

In the same way, the famous tribal leader Geronimio is represented by the whites as "the savage beast Geronimo" (Silko, 1992, p. 225) in Almanac of the Dead. Contexually, the lexical selection reaffirms the Euro-Americans' mission of civilizing the 'uncivilized.' For the Natives, the concept of photograph was too new and unique to be perceived by their naivety. The white man asked the youngest Geronimo (Sleet) to be photographed by "selecting desert background for his photo" and gives 'a lot of attention to an Apache woman wearing "a huge feathery warbonnet" (p. 226). Selection of the background, which denotes an important discursive strategy of presenting 'self' and 'others', is meant to promote the colonial hegemony through differentiation. Ironically none of the Apaches ever wore any similar headpiece. Moreover, Sleet 'dresses up' according to the 'precise directions' of the photographer. The photographer makes him slightly stand to one side so that "the long, trailing cascade of chicken and turkey feathers could be fully appreciated in the profile view" (p. 226). Interestingly the 'direction' given does not focus on the native but only his exotic appearance. Big Pine was also photographed with posing "45-70 across his lap." Interestingly, he had never used this rifle. Also, it had lost its "firing pin". It's "barrels were jammed" due to no usage. Through the photograph the white police mistook Big Pine as a Geronimo and this confusion resulted in his arrest. This is how photographing started misrepresenting the truth. However, gradually the natives started realizing the economic agenda behind the white's practice photographing them. After this realization, many 'so-called Geronimos' started using their poses for monetary benefits (p. 228). So, the entire photographing process becomes a mean for getting money.

Similar issue has been highlighted in the chapters named 'The Stone Idols' and 'Hollywood Movie Crew'. Euro-Americans have 'stolen' natives' sacred stone idols and placed them in history museums. Silko defines them as "horrible white people" and "some of the worst people on the earth" (p. 89). They take money from the tourists to view these idols. According to the natives, this practice violated the sanctity of these idols which they associated with nature and, so, environmental harmony as well. The idols had the title and, so, status as "Little Grandmother" and "Little Grandfather". The whites also tried to get 'bones and skin' of their ancestors from 
their graves' for 'cash'. This buying and stealing of these sacred objects by the whites meant highly ignoble for the Natives.

After labeling the natives as commodities, the colonizers started exploiting, as the next measure, the natives through their newly established laws, economic and political, which were meant not only to serve their materialistic interests but uphold their superiority in power structure. This politics is manifested in the description of the character of Guzman who first illegally takes away the natives' land and then uses it for mining purposes. Majority of Indians were confused about the function of the relevant documents. So, they sold their lands unknowingly.

Gradually, the prospects of Uranium mining started attracting more and more whites who 'rushed into the area' and who also indulged in stealing precious metals from the land through mining. "It was white men coming to find more silver, to steal more Indian land. It was white men coming with their pieces of paper! To make their big ranches. Guzman and my people had made an agreement" (Silko, 1992, p. 116). Resultantly, with no other viable option left, natives were compelled to sign with Guzman a deal of equal profit sharing in exchange of their lands. Consequently, the land turned into merely a site of profit making and law became a 'piece of paper' for legitimizing the illegitimate (p. 117).

\subsection{Attempt to Resolve the Difference}

Silko also offers solutions to resolve the conflict of nature/culture and civilized/uncivilized. She does it, first, by deconstructing the myths of the colonizers which the latter had established to form a discourse, and through it a knowledge, to implement their agenda, and, then, by trying to communicate this to the Natives in particular and the world in general. Criticizing the colonizer's attempt to impose their knowledge and truth, she explains that knowledge is always relative, temporally, spatially and culturally, and, so, fits only its relevant culture. She is sarcastic about the Europeans' understanding of 'knowledge'. She elaborates this subtle point through the character of the father of Zeta and Lecha. The character has no name and, so, no identity. He personifies an entity that has no value like scientific knowledge. He is a geologist by profession - and a geologist, according to him, is a scientific reader of land - and calls himself 'imperfect vacuum' (Silko, 1992, p. 121). The term vacuum symbolizes the hollowness of the scientific knowledge of Europeans. Like a vacuum, he ends up loving nothing "not his wife, not his daughters, not science, not rocks, not even himself" (Silko, 1992, p. 121). He considers his knowledge as accurate and authentic and always tries to get it verified by others too. Yeome, as a native, disagrees to this view. She has a staunch conviction, which she preaches as well, that this knowledge has "violated the Mother Earth" (p. 121). She advises that the knowledge relative to the native culture must reconcile with the essence of this culture, as the real meanings could be apprehensible only when the subtleties of the natives' culture can be viewed through the naked eyes of the natives themselves. So, contextually, with the death of the geologist who dies unnamed, western and Euro-American philosophy of science fails along with all its claims.

Secondly, Silko proposes that when one faces denial in a racial space, one should search for his own comfort zone instead of seeking escape or compromise. He should function like a normative outside the boundaries of race. Therefore, the natives, being on margins, can also assess the true nature of racial labels. From these margins, they should challenge the very labels through which they are described. Racial space, being a discursive phenomenon fundamentally, will never protect the natives. Their survival in the world and ability to cope the hardships depend on their individual struggles. Tayo's status as Native American is worthless outside the reservation. His white blood also makes him less significant among the natives. He faces exclusion from the entire society yet he does what he can to continue being social. But, when he realizes that his efforts to reunite himself with his society are turning futile, he creates his own intellectual, psychological and emotional domain. $\mathrm{He}$ reconsiders his 'self' and recreates it. In this newly gained knowledge and consciousness, he feels himself complete. Moreover, in this newly gained 'regime of truth', he initially starts labeling others as 'other'. Then he also starts questioning these very labels. His medicine man, Betonie, also advises him to see beyond labels of being an Indian or white. As an alternative, he should value those individuals who reside in these formerly imposed and determined racial spaces. Betonie suggests him "don't be so quick to call something good or bad. There are balances and harmonies always shifting, always necessary to maintain... It is a matter of transitions, you see; the changing, the becoming must be cared for closely" (Silko, 1986, p. 130).

Likewise, Silko deconstructs the myths created and disseminated by the colonizers for their power discourse. Her witch story predicts the colonizer's agenda that one day "white skin people" will come to all of the Indian lands. She describes these peoples as the ones who "grow away from the earth... from the sun... from the plants and animals". 'Growing away from natural objects' paradoxically signifies, first, the colonial objectification of the 
surroundings and their superiority over nature and second and more vigorously the natives' objectification of the colonizers themselves.

Finally, attempting to resolve the difference, Silko reinforces the reconsideration of the reunion of man with nature. Human healing is only possible within a balanced environment. Silko equalizes this healing with the healing of Tayo. His healing is accompanied by his changed attitude towards the environment. He even becomes respectful to "the lowliest of life forms - the insects". He does not enter into a café which is adorned with "sticky flypaper' although the owner sees killing flies as "serious business" (Silko, 1986, p. 101). Even when he walks on the grass, he steps carefully "pushing the toe of his boot into the weeds first to make sure the grasshoppers were gone before he set his foot down" (p. 155). He also memorizes native stories about "time immemorial" whilst "animals could talk to human beings" (p. 4). This affinity between human beings and animals used to rescue the people from destruction. After returning from war, he restores his long-lost connection with his cultural roots at his Laguna Pueblo reservation. He feels peaceful when he reconnects with his familiar and healing landscape. Presenting the poem of animals and making it parallel to the human character also makes this point clear that in the Native American culture there exists a complete harmony between humans and non-humans and the mother-nature. Since man is a part of nature, as are all other non-human objects, his healing is possible only when it synchronizes with the healing of the mother-nature.

\section{Conclusion}

Silko's Ceremony and Almanac of the Dead reveal that the environmental discourses serve the environmental agenda of the colonizers, which are manifested in the form of biocolonization in the context of the study. In the selected texts, Silko highlights the subtle process of the formation, establishment and perpetuation of this dominant environmental discourse and views it as 'a system of allocation' which is based on the ideology of colonial power structures reflecting their adverse attitude towards nature and the earth and its environment. These power structures are then used to gain profit by making the natives and nature as 'others', the subordinate, and the 'objects of sympathy'.

This entire process of construction serves twofold agendas of the colonizers: first to constitute 'others' like Tayo, Emo and Geronimo and commodify them as 'exotic and wild entities' and second to get profit by marketing their wildness that can be seen in Gallop Ceremonial and the event of photographing. Moreover, the colonizer's policy to push the natives to unfriendly 'reservations' and to label them as 'second-class citizens' reaffirms the commodification of indigenous people and their lands. This commodification is paralleled with the colonizers 'feeding off the man and his environment'. Besides, stealing sacred objects of natives and displaying them in museums to earn money also explores profitable functioning of colonial web. This profitable business is maintained via self-serving economic and political laws. Additionally, the witch story as highlighted by Silko, which predicts that one day "white skin people" will come and steal all of the Indian lands, is also a discursive tactic employed by the colonizer. Thus, the tactful employment of discourse strategies by the colonizers culminated into a common sense ideology which served the fulfillment of the colonizers' interests and violated nature, environment and the interests of the natives.

Second, Silko also offers, in her texts, a counter narrative which suggests that the survival of Native Americans primarily requires due knowledge to resist the colonizer's discourse and, so, the acceptance of the foisted truth. It is through this knowledge, which is discursive in nature, that the natives can challenge the anti-human and anti-environment colonial power structures. She reinforces the reconsideration of the reunion of man with nature. This reunion can be seen in Tayo's healing which is accompanied by his changed attitude towards the environment. Her story of corn-woman is also a part of her counter narrative which suggests that human healing is possible only in synchronization with the healing of nature.

\section{References}

Bakhtin, M. (1981). The Dialogic Imagination (ed. M. Holquist). Austin: University of Texas Press.

Fairclough, N. (1989). Language and Power. London: Longman.

Fairclough, N. (1995). Discourse and Social Change. Cambridge: Polity Press.

Fairclough, N. (1995a). Critical Discourse Analysis. London: Longman.

Fairclough, N. (2003). Analyzing Discourse: Textual Analysis for Social Research. London: Routledge. https://doi.org/10.4324/9780203697078

Foucault, M. (1972). The Archeology of Knowledge. London: Tavistock Publications.

Huggan, G., \& Helen, T. (2006). Postcolonial Ecocriticism: Literature, Animals, Environment. London: 
Routledge.

Lazar, M. M. (2005). Feminist CDA as Political Perspective and Praxis. In M. M. Lazar (Ed.), Feminist Critical Discourse Analysis, Gender, Power and Ideology in Discourse. Basingstoke. https://doi.org/10.1057/9780230599901

Lemke, T. (2011). Biopolitics: An Advanced Introduction. London/New York: New York UP.

Mikinori, N. (2009). A consideration of the Concept of Hegemony in term of Critical Discourse Analysis focusing on Intertextuality and Assumptions. Gifu City Women's College, 59, 15-21.

Nadesan, M. H. (2008). Governmentality, Biopower, and Everyday Life. New York: Routledge.

Patton, M. (2002). Qualitative Research and Evaluation Methods. Thousand Oaks, CA: Sage.

Plumwood, V. (2003). Decolonizing Relationships with Nature. In H. A. William \& M. Martin (Eds.), Decolonizing Nature: Strategies for Conversation in a Post- Colonial Era (pp. 51-78). London: Earthscan.

Silko, L. M. (1986). Ceremony. New York: Penguin Books.

Silko, L. M. (1992). Almanac of the Dead: A Novel. New York: Penguin Books.

Stoler, A. L. (1995). Race and the Education of Desire: Foucault's History of Sexuality and the Colonial Order of Things. Durham/London: Duke UP.

Tong, R. P. (1998). Feminist Thought; A More Comprehensive Introduction (2nd ed.). Allen and Unwin.

Whitt, L. (2009), Science, Colonialism, and Indigenous Peoples: The Cultural Politics of Law and Knowledge. Cambridge: Cambridge University Press. https://doi.org/10.1017/CBO9780511760068

Wodak, R., \& Meyer, M. (2001). Methods of Critical Discourse Analysis. London: Sage Publications. https://doi.org/10.4135/9780857028020

\section{Copyrights}

Copyright for this article is retained by the author, with first publication rights granted to the journal.

This is an open-access article distributed under the terms and conditions of the Creative Commons Attribution license (http://creativecommons.org/licenses/by/4.0/). 